\title{
A Review of Sustainable Materials to Improve Geotechnical Properties of Soils
}

\author{
Farah Qais Al-Naje ${ }^{1}$, Alaa Hussein Abed ${ }^{2}$, Abbas Jawad Al-Taie ${ }^{3}$
}

\section{Authors affiliations: \\ 1) Civil Eng. Dept., Al-Nahrain \\ University, Baghdad-Iraq. \\ f17a5r85h@yahoo.com}

2*) Civil Eng. Dept., Al-Nahrain

University, Baghdad-Iraq.

Alaa.abed@eng.nahrainuniv.edu.iq

3) Civil Eng. Dept., Al-Nahrain

University, Baghdad-Iraq.

abbas.altaie@eng.nahrainuniv.edu.iq

\section{Paper History:}

Received: $2^{\text {nd }}$ Feb. 2020

Revised: $5^{\text {th }}$ March 2020

Accepted: $14^{\text {th }}$ Aug. 2020

\begin{abstract}
Most of the soils suffered from significant geotechnical problems dependent on factors like the type of soil, soil composition and mineralogy. Especially, the problems related to mechanical and physical properties of soils. Several studies have been used to mitigate the adverse effects of soils through using either additive conventional materials such as cement, lime or these soils blending with produced material and chemical materials. Recently, additives from industrial, agricultural, domestic, and mineral wastes have been used to improve soils. According to literatures, such wastes have been classified as sustainable materials. This paper focuses on stabilizing or improving different soils using sustainable materials. These materials provided engineering and economic benefits through improving the geotechnical properties of soil. According to the results of this review, the effect of different sustainable materials on compaction characteristics, California bearing ratio and unconfined compressive strength have been studied and discussed in this paper.
\end{abstract}

Keywords: Sustainable Materials, Soil Improvement, California Bearing Ratio, Unconfined Compressive Strength, Compaction, Environmental.

\section{Introduction}

The concept of soil improvement presented, increase strength, provide volume stability, reduce deformability, reduce permeability and enhance the durability of soil Fatani and Alzahrani [1]. The scientific techniques of soil stabilization either using of cementitious material like Portland cement, hydraulic lime has been investigated by many researchers Petrenko et al, Liang et al and Sharo et al)[2-4] or mixing with the correct proportion of sandy and clay soil or by mechanical compaction of natural soils, two research by Al-Taie and Al-Shakarchi [5-6], Hussein et al, Al Taie et al [7-8].

The production of cement has severe environmental impacts, using large amounts of fossil fuels lead to speared and emission of more than $5 \%$ of carbon dioxide worldwide Cristelo et al [9]. Hence, the use of the alternative cementitious materials in soil stabilization application has been studied and recorded a noticeable performance. These materials are called sustainability cementitious materials that are waste or by-products and possess hydraulic and pozzolanic characteristics Rios et al [10]. The advantage of these materials stabilized the soil and it more economic in the filed construction and significant reduction of environmental pollution. A review regarding improving different soils using environment friendly materials such as fly ash, cement kiln dust, ground granulated, blast slag, rice husk ash etc. was presented in this paper.

\section{Natural Soils Problems:}

The geotechnical problems of soils such as bearing failure, differential settlements, hydrocompression, ground heave, instability, liquefaction, erosion, and water seepage have been studied by Han [11]. The problems of natural soils in geotechnical applications can be simulated in the following table (1)

Table. (1) Illustrated the problematic soils by Han (2015) [11] modified

\begin{tabular}{|l|l|}
\hline $\begin{array}{l}\text { Type of } \\
\text { soils }\end{array}$ & Problems \\
\hline soft clay & $\begin{array}{l}\text { Low strength, high compressibility, } \\
\text { large creep deformation, low } \\
\text { permeability }\end{array}$ \\
\hline Silt & $\begin{array}{l}\text { Low strength, high compressibility, } \\
\text { high liquefaction potential, low } \\
\text { permeability, high erodibility }\end{array}$ \\
\hline $\begin{array}{l}\text { Organic } \\
\text { soil }\end{array}$ & $\begin{array}{l}\text { High compressibility, large creep } \\
\text { deformation }\end{array}$ \\
\hline
\end{tabular}

NJES is an open access Journal with ISSN 2521-9154 and eISSN 2521-9162

This work is licensed under a Creative Commons Attribution-NonCommercial 4.0 International License 
NJES 23(3)289-305, 2020

Al-Naje et al.

\begin{tabular}{|l|l|}
\hline $\begin{array}{l}\text { Loose } \\
\text { sand }\end{array}$ & $\begin{array}{l}\text { Low strength, high compressibility, } \\
\text { high liquefaction potential, high } \\
\text { permeability, high erodibility }\end{array}$ \\
\hline $\begin{array}{l}\text { Collapsible } \\
\text { soil }\end{array}$ & $\begin{array}{l}\text { Large volume change Al-Taie et al. } \\
{[12]}\end{array}$ \\
\hline $\begin{array}{l}\text { Expansive } \\
\text { soil }\end{array}$ & $\begin{array}{l}\text { Large volume change Al-Jeznawi et } \\
\text { al. }[13]\end{array}$ \\
\hline
\end{tabular}

Furthermore above mention problems, the subgrade during winter seasons, movement water table, and heavy traffic may cause migration fine particles from the subgrade to the subbase layers, this phenomenon has been investigated by Kermani et al [14] and discussed the major contributor in faulting and pavement failure. Tiwari et al. [15] studied the cracking roads and floor due to the uplift subgrade of the road (expansive soil) and floor slab. This reason belonged to the expansive soils contain minerals that absorb the water then, lead to an increase in its volume.

\section{Types of Sustainable Materials According to Their Sources \\ 1-Industrial Waste: \\ Cement Kiln Dust}

CKD a waste by-product of Portland cement manufacture. This material considered a storage problem, health hazard, economical solution.

Baghdadi et al. [16] utilized Cement kiln dust in order to treat dune-sand ( SP). For light applications, it was expected that $12-30 \%$ should be tolerance to upgrade dune sand, while for heavily loaded applications, it was required to raise the CKD content to about $50 \%$. However the percentages between 12 and 50\% may be satisfactory but if increased it to $75 \%$ and $100 \%$ CKD, that led to failure in durability. Due to void filling with CKD and cementing particles of soils, maximum dry

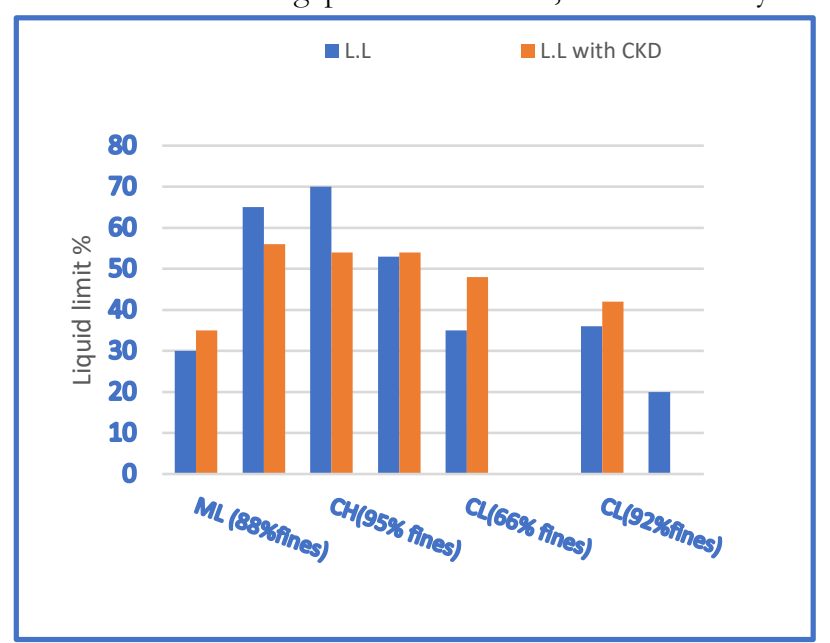

density (MDD) and California bearing ratio(CBR) increased up to a point around $50 \%$ CKD content, after which the MDD and CBR continue to reduce while optimum moisture content (OMC) decreased at adding CKD around $0 \%-40 \%$ then increased.

Three types of soils have been investigated by Miller and Azad [17] (CH, CL, ML). The dosage of CKD was (5\%-30\%) increment 5\%, the optimum CKD content at $25 \%$. The result of this study showed increased in unconfined compressive strength UCS, significant reductions in plasticity index $(\mathrm{PI})$ and maximum dry density (MDD) while optimum moisture content (OMC) increased with CKD treatment.

Miller and Zaman [18]evaluated the difference in the effectiveness of CKD from three different Portland cement producers and comparable with lime to enhance the soil. The results have advantages better than lime. Lime is considerably a classic modifier of cohesive soils, whereas CKD both modifies and stabilizes. Regarding the improvement of strength, the development of strength in soil treated with CKD found more quickly. The mixing and compaction process in the mixture of soil and CKD does not require a delay time in comparison to that required for soil mixed with quicklime. CKD is effective at stabilizing both cohesive and cohesionless soils.

Parsons et al.[19] investigated eight soils (three $\mathrm{CH}$ soils, two CL soils, ML, SM, and SP). Effectiveness of $\mathrm{CKD}$ as a stabilizer for these soils have been studied and recorded different ratio improvement according to the type of soils at optimum percentages of CKD added. Figures (1) to (3) show the responses of different soils to CKD as a stabilizer. It can be noted that the plasticity of soil is highly affected by CKD content. High improvement can be seen for soil strength with the content of the stabilizer.

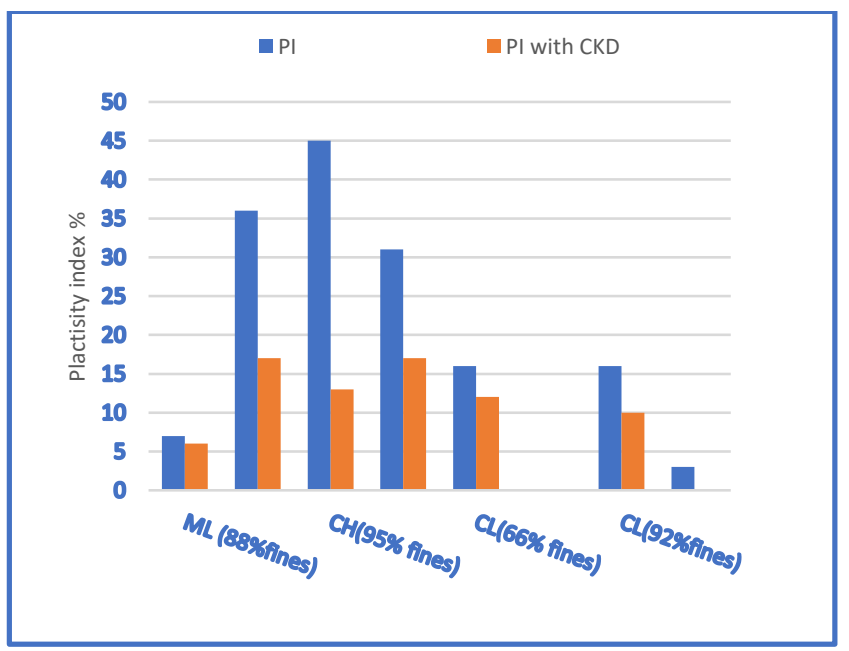

Figure (1): Effect of CKD on Atterberg Limits. 
NJES 23(3)289-305, 2020
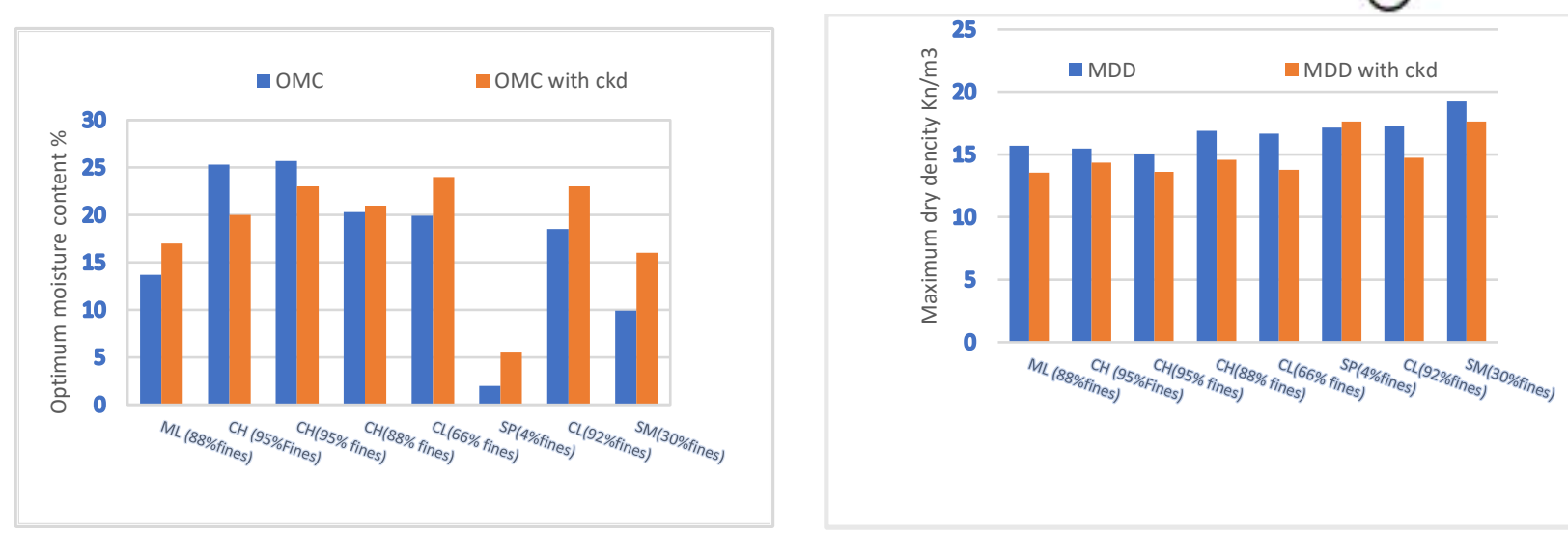

Figure (2): Effect of CKD on Compaction Characteristics.

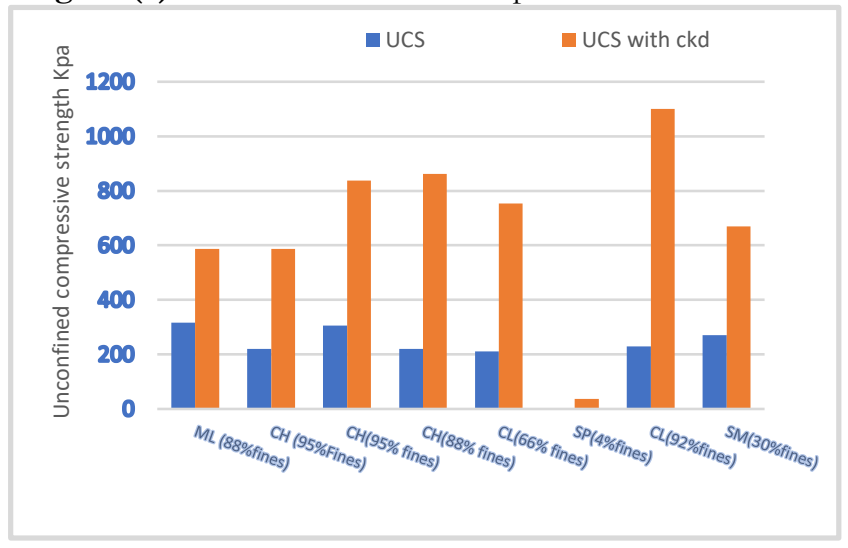

Figure (3) Effect of CKD on Unconfined Compressive Strength.

Amadi [20], Jimoh et al. [21] investigated the use of cement kiln dust (CKD) to enhance the durability of black cotton soil (BC soil) subgrade modified with quarry fines $(\mathrm{QF})$. Specimens were prepared with $\mathrm{BC}$ soil mixed with a constant dosage of $10 \%$ QF and five levels of CKD proportions $(0 \%, 4 \%, 8 \%, 12 \%$, and $16 \%$ by dry weight of soil). Test results show that each liquid limit, plastic limit, and plasticity index decreased with added of CKD. Mixtures at $0 \%$ and $4 \%$ CKD lead to failed the CBR, swell limits and loss of the strength criterion while mixture having $8-16 \%$ CKD satisfied results of the CBR and swell requirement as well as strength immersion criterion. The maximum dry unit weight increased on the addition of quarry fines. Dry unit weights were thereafter generally lowered when CKD was introduced. The optimum moisture content, on the other hand, increased for the natural soil when QF was added. The addition of $\mathrm{QF}$ together with $\mathrm{CKD}$ to the $\mathrm{BC}$ soil revealed $\mathbf{a}$ noticeable performance to improve soil structural properties by increasing the unconfined compressive strength UCS almost linearly with increases in the CKD content.

Hossain [22] used various combinations of Cement kiln dust and rice husk ash as stabilizers in different percentages (maximum up to $20 \%$ ) to develop and evaluate stabilized clayey soils. CKD-stabilized soils showed higher strength, elastic modulus, shrinkage values, $\mathrm{CBR}$, water resistance, while the water absorption (sorptivity) is lower in comparison to their RHAcounterparts.

AI-Homidy et al. [23] investigated the feasibility of utilizing CKD for improving the properties of weak soiI such as SM or SC soils (Sandy soil or Muddy soil consisted of sandy carbonate mud soil). Soil samples are prepared with $2 \%$ cement and $10 \%, 20 \%$, or $30 \%$ CKD. It is observed that the soil blended with $2 \%$ cement, and $30 \% \mathrm{CKD}$ could be used as a sub-base material in rigid pavements. However, the use of $30 \%$ CKD can contribute to mitigating the consumption of cement by $5 \%$, which, in turn, leads to environmental and economic benefits. The results of this study prove optimum moisture content, california bearing ratio and unconfined compressive strength increased while maximum dry density decreased.

Cui et al. [24] studied mitigation a dramatic problematic for expansive soil through added different CKD content ratios, ranging from 0 to $18 \%$ by dry mass soils but the optimal of CKD content is between 10 and (14) \%. The results of this study show that CKD can improve the long-term strength of expansive soil. Both the size and amount of macro-pores and micro-pores decrease with an increase in CKD content. Saturation 
and hydration processes have occurred on the soil structure then, it became more dispersive and possed lower strength. However to restrain these processes, adding CKD was a significant performance.

Mohammadinia et al. [25] utilized the incorporation of two waste materials in order to strength and stiffness of demolition waste aggregates. (CKD) and fly ash (FA) which has a rich source of calcium, silica and alumina. This research has been presented three major compenents of the demolition waste firstly, (Recycled concrete aggregate (RCA), secondly, Crushed Brick(CB), finally Reclaimed Asphalt Pavement (RAP)) to assess the efficiency of the stabilization process. The optimum ratio of FA:CKD around 50:50 proven a remarkable improvement. However, alkali-activation of $15 \%$ CKD and $15 \%$ FA mixed with an aggregates type $\mathrm{C}$ and $\mathrm{D}$ can obtain a good blend to use as construction materials. With higher CKD content, the higher surface area and high-water absorption of the CKD leads to a higher water content of the mixture. On the other side the spherical FA particles facilitated the rearrangement of the aggregate which, in turn, reducing the OMC of the mixes with higher FA content. Although the densities were constant, they were slightly increased with CKD.

Mahdi et al. [26] studied the effect of the cement kiln dust (CKD) as a stabilizer for subbase type (B) to $20 \%$ by weight. Both density and optimum moisture content were clearly increased when the CKD content increased. The percent more than $15 \%$ of CKD make increasing in CBR and UCS to more than $115 \%$ and 55\% respectively. Results indicated that there is the ability to use the CKD as an alternative material for cement

Naseem et al. [27] had studied the effect of tire rubber powder (TRP) and cement kiln dust (CKD) in order to improve low shear strength, bearing capacity and other swelling parameters for expansive soils. The percentages were about 5\% TRP and 5, 10, 15,20, 25\% CKD. It was found that the optimum content is at $5 \%$ TRP with $10 \% \mathrm{CKD}$, the plasticity of soil was reduced with the addition of TRP and CKD. MDD was increased, also UCS was increased up to peak value at $5 \%$ TRP, but when added $10 \%$ CKD, the increase in UCS and CBR values reached $277 \%$ and $249 \%$ of the initial strength respectively.

Shukla and Tiwari [27] investigated clayey soil (type, $\mathrm{CH}$ ) that demonstrated expansive behavior and make higher swelling and shrinkage property during dry and wet states then these phenomena lead to a loss in strength of the soil. To modify the engineering properties of the subgrade clayey soil, soil blending with different percentage of cement kiln Dust as 5\%,10\%, $15 \%, 20 \%$, and $25 \%$ by weight. The results of this study were decrement in the swelling potential of soil when the percentage reached $25 \%$ replacement of soil also, the optimum moisture content (OMC) decreases and maximum dry density (MDD) increases with increased CKD up to $25 \%$. UCS and CBR value increased with increased $\mathrm{CKD}$, CBR reached up to double value as compared to the raw soil.

Expansive soil samples from southwestern Baghdad have been prepared and blended with different contents of cement dust, (4 to 20$) \%$, by Almurshedi [29]. This modifier considerable observation method to improve geotechnical properties of this soil such as decreasing the consistency limits, (L.L, P.L., P.I), increasing the maximum dry density corresponding to lower optimum water content, decreasing the swelling pressure and swelling potential. unconfined compressive strength improved by $8 \%$ with increasing cement dust content to $16 \%$.

Al-Baidhani and Al-Taie [30] presented a review that included many materials used as a stabilizer for expansive soil such as CKD. They noted that the plasticity index of the montmorillorillonite clay reduced, improvement in shear strength, reduced maximum density of the soil, while the values of optimum moisture content and Califonia bearing ratio were increased.

Rimal et al [31] treated two natural soils (ML and CL soils) with several proportions of CKD for various curing periods. The percentages were $(2.5,5,7.5,10 \%)$. The MDD and OMC increased with added CKD. At fourteen days curing, the UCS increased and reached high value about ten times with increased CKD .

From overall group researchers can make a chart as shown in Figure (4). The adding of CKD to all engineering types soils has been demonstrated that CBR values were more efficient in NP soils. CBR values recorded slightly dropped at $\mathrm{CH}$ and $\mathrm{CL}$ soils, this reason belonged to the usage of incorporation of CKD with other materials such as quarry fines $(\mathrm{QF})$, rice husk ash (RHA). A noticeable performance in SP can be observed, this reason deported to a lack in the ratio of fine aggregates. However, the usage of $30 \% \mathrm{CKD}$ with $2 \%$ cement at SM or SC soil considered a significant reduction in cement consumption. 


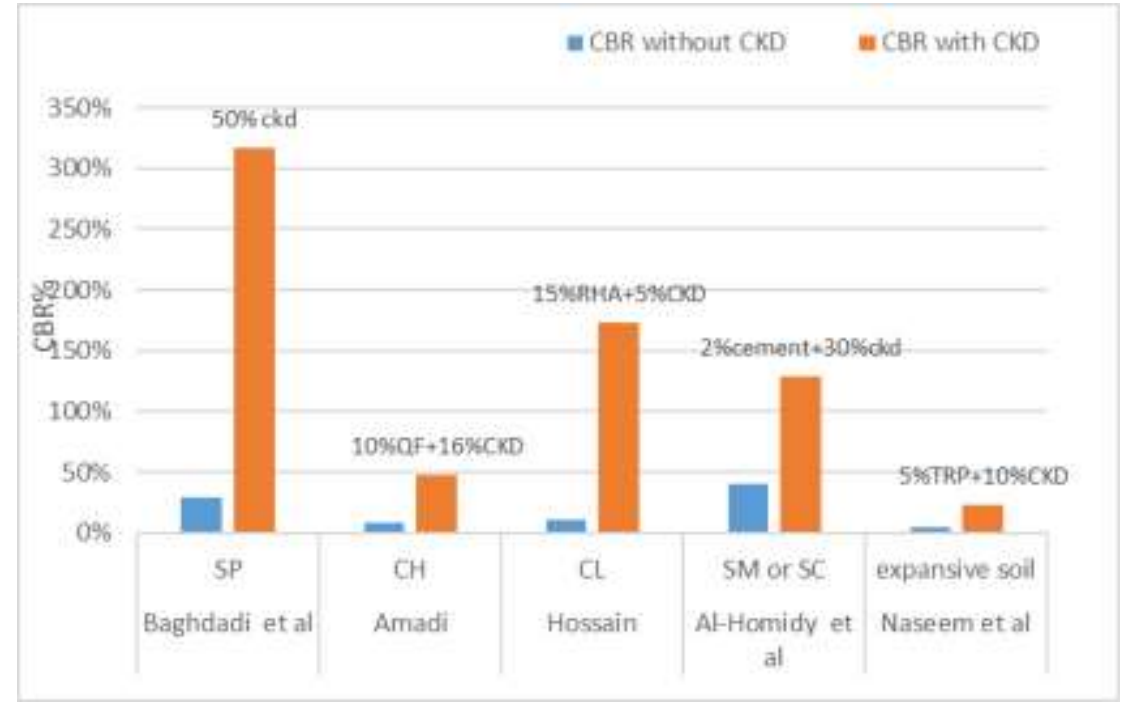

Figure (4): $C B R$ values respected to different researchers with and without $C K D$ and other materials.

Figures (5) and (6) illustrated the behavior of CKD in sandy soils different than clayey soils. In sandy soil, the first MDD increased with higher CKD due to the voids between sand particles filled with CKD particles. After that, MDD decreased because CKD continued to react with water due to calcium oxide in CKD loved water. The Interpretation in clayey soil, MDD decreased with CKD adding, due to pozzolanic stabilizer can be bind soil particles together and reduce water absorption by clay particles.

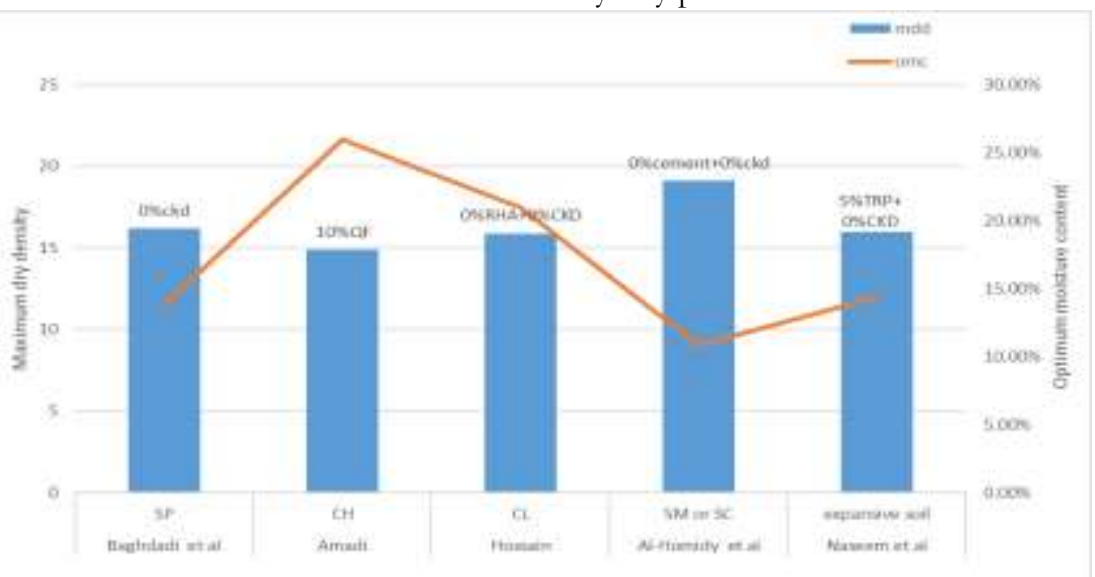

Figure (5): MDD and OMC respected to different researchers without CKD.

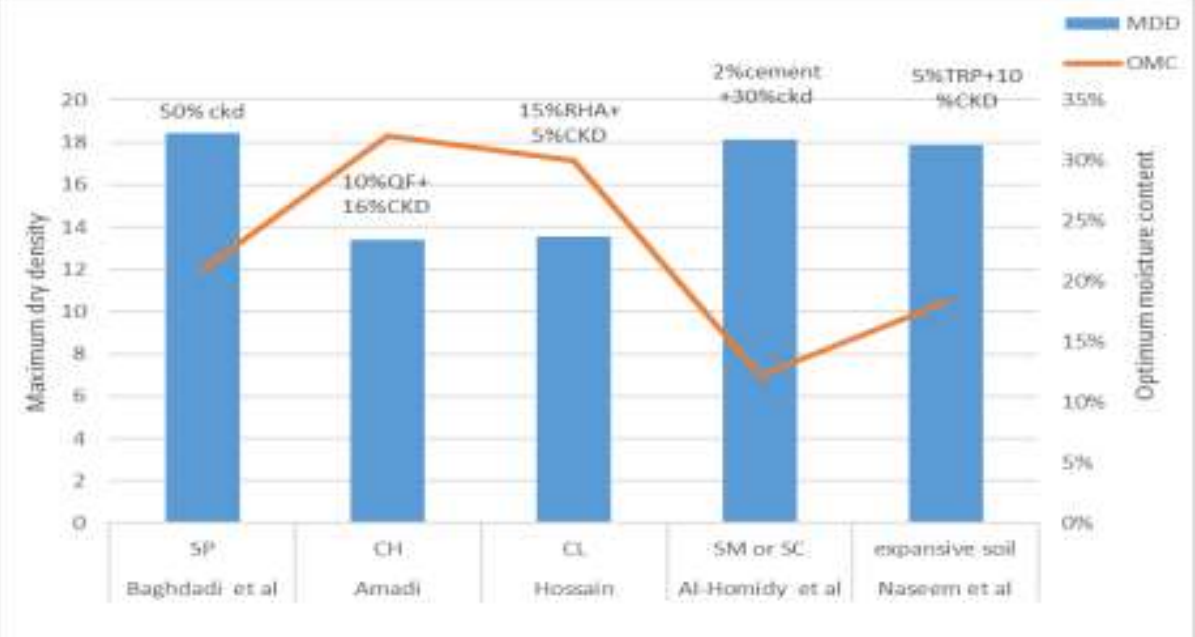

Figure (6): MDD and OMC respected to different researchers with CKD 


\section{Red Mud}

Red mud, RD, is a byproduct of the bauxite industry. Kalkan [32], Kocserha et al [33], and Sridevi et al [34], respectively studied the effect of red mud (RD) on geotechnical characteristics of the clay soil. Kalkan stabilized expansive soil with RD and found an increase in strength and decrease in hydraulic conductivity and swelling percentage. Kocserha et al. examined the effects of red mud addition on clays with and without earth alkali carbonate content. They were stated that the increase in MDD increases red mud up to $40 \%$. Sridevi et al. used red mud with lime and fly ash with lime then, using this mixture as a stabilizer of expansive soil. Red mud, as well as fly ash, stabilized with $4 \%$ lime, and this mixture is added to the expansive soil in various percentages serious, 10 to $50 \%$ in increments of $10 \%$. As a result, the geotechnical properties of the soil improved. Fly Ash

Kolias et al. [35] investigated the effectiveness of using high calcium fly ash and cement in stabilizing two fine-grained soils, high plasticity $(\mathrm{CH})$, and low plasticity (CL) clays. The percentages of fly ash (FA) and cement (C) used were $(5 \%, 10 \%$, and $20 \%)$ and $(2 \%$, and $4 \%)$ by weight of soil respectively. The results indicated that the soil became non-plastic after mixing with fly ash. The MDD and OMC increased as fly ash added. At 10\% fly ash with 4\% cement, the UCS value revealed the highest levels. Zhang and Solis [36] had used fly ash as a suitable stabilizer of local gypsiferous soil. soil samples were treated with varying the percentages of $(10 \%, 15 \%, 20 \%, 25 \%)$ of fly ash with gypsiferous soil. Based on the results obtained from the laboratory testing on gypsiferous soils before and after the addition of fly ash, the strength is increased when the curing period is increased.

Han-bing et al. [37] investigated the effect of additive fly ash on silty clay soil in order to enhance this soil. The proportions of fly ash to soil 1:4, 1:2 and 1:1. The results of the strength index at 1:2 was tolerable and better than another ratio. The frost heave decreases with raised of fly ash.

Senol et al. [38] improved the engineering properties of the low plasticity clay subgrade by blending the soil with Class C fly ash and Virgin Homopolymer Polypropylene (VHP). The best results were achieved when soil mixed with $10 \%$ of fly ash and $0.25 \%$ of VHP. The unconfined compressive strength (qu) of the low plasticity clay increases and reaches a peak value of approximately $200 \%$ when the fly ash content $10 \%$ and $0.25 \%$ of VHP. On the other side, at $15 \%$ fly ash content, the increase in qu was dramatic decrease which could be even neglected. The OMC decreased, at fly ash content increased.

Sabat and Moharana [39] investigated the effects of compaction energy on engineering properties of an expansive soil by using the fly ash-granite dust as a stabilizer on it. The maximum dry density increased and optimum moisture content decreased with compaction energy increased, so the soaked CBR increased and UCS increased at 42\% FA-GD, however, UCS goes on decreasing when FA-GD overflow $42 \%$.

Turan et al. [40] studied the effects of consistency, swelling and strength characteristics of class C fly ash with one day curing period as a stabilizer for clayey soil. This type of stabilizer considers as eco-friendly. The results prove that the addition of fly ash leads to mitigate of the plasticity index, the swelling, and the compressibility index, on the other side compressive strength increased. The maximum dry density decreased while optimum moisture content increased at $5 \%$ fly ash by dry weight of the Soil. At fly ash content increased up to $30 \%$, both of MDD and OMC have been taken a reverse trends. UCS increased gradually with increasing fly ash content up to $30 \%$.

Ige and Ajamu [41] determined the dosage of fly ash that would be added to sandy soil in order to obtain the optimum stability of the soil and enhancement of physical and engineering properties of soil. At $40 \%$ of fly ash has the greatest effect on the increment of the compressive strength of the sandy soil. At 10\% addition of fly ash replaced with a mass of bulk sand and recompact. This, however, is the same for $20 \%, 30 \%$, $40 \%$ and $50 \%$. MDD decreased while OMC, increased with added of Fly Ash.

Sabat and Mohanta [42] investigated the potential added Fly ash to an expansive soil stabilized with 9\% limestone dust. It was found that expansive soil stabilized with $9 \%$ limestone dust and 15\% fly ash, can be successfully utilized as a material for subgrade in the pavement. From the compaction test, MDD decreased and OMC increases with the rise in addition to fly ash.

From the above mentioned, the effect of the addition of Fly ash alone or combination with another material on varying soils is illustrated in the following table (2) and figures(7) and (8). Figure (7) show that MDD and OMC decreased and increased respectively with added fly ash alone to soil has fine grains. This reason belonged to the specific gravity of fly ash less than soil, while MDD increased in sandy soil. However, additional combination materials lead to raise MDD and drop OMC due to Gs for these materials more than Gs of soil.

Table. (2) included some researches details which regarding in type of soil and percentages of additives.

\begin{tabular}{|c|c|c|c|c|c|}
\hline Researchers & Senol et al. & $\begin{array}{c}\text { A.K.Sabat and } \\
\text { R.K Moharana }\end{array}$ & Turan C et al. & $\begin{array}{c}\text { A.k .Sabat and S } \\
\text {.Mohanta }\end{array}$ & $\begin{array}{c}\text { Ige. J.A and } \\
\text { Ajamu. S.O }\end{array}$ \\
\hline Type of soil & CL & CH & CI-CL & $\begin{array}{c}\text { CH(expansive } \\
\text { soil) }\end{array}$ & Sandy soil \\
\hline proportions & $\begin{array}{c}10 \% \text { fly } \\
\text { ash }+0.25 \% \mathrm{VHP}\end{array}$ & $55 \%$ FA-GD & $5 \%$ fly ash & $20 \%$ fly ash & $40 \%$ fly ash \\
\hline
\end{tabular}


NJES 23(3)289-305, 2020

Al-Naje et al.
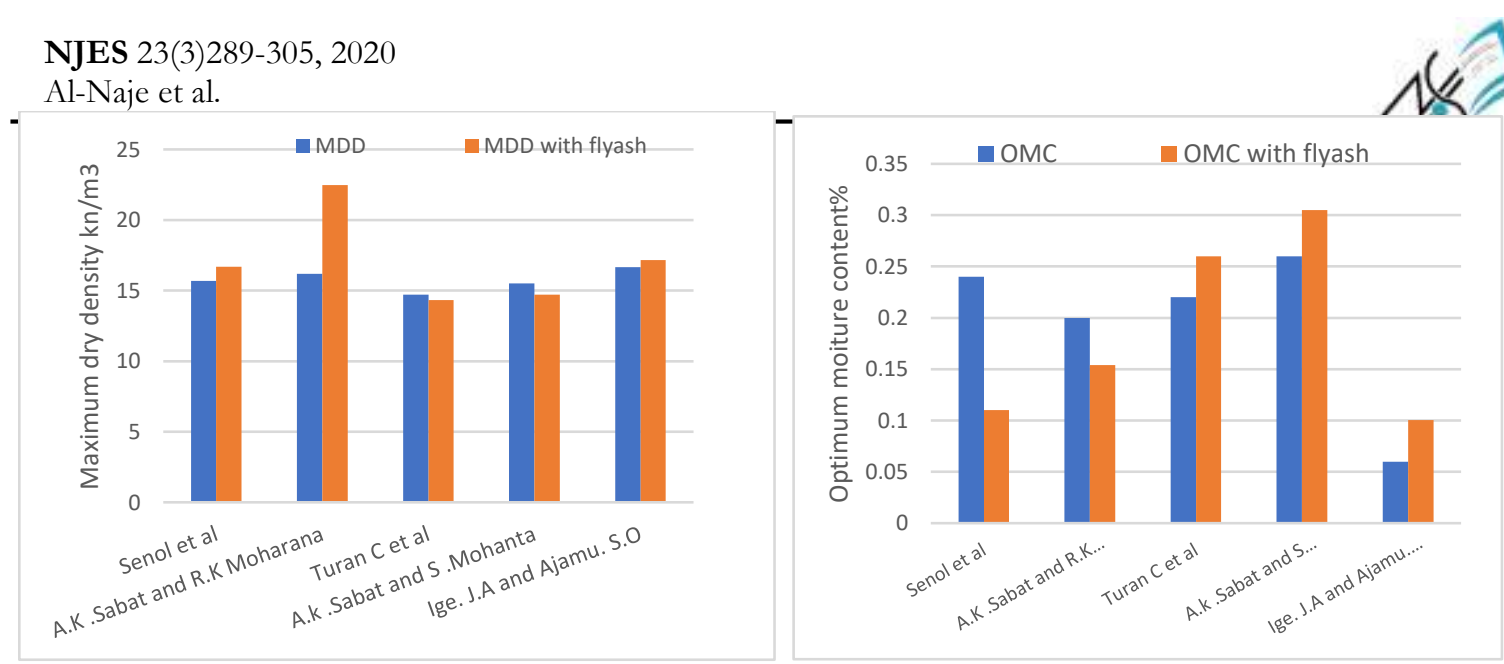

Figure (7): MDD\& OMC respected to different researchers.

Figure (8) illustrated the effect of fly ash on CBR for different soils. The spherical particles of fly ash filled all pores or voids. Based on the existence of water in soils leads to occurrences a pozzolanic reaction, as a result of a significant interlocking between particles of soil, consequently increase UCS.

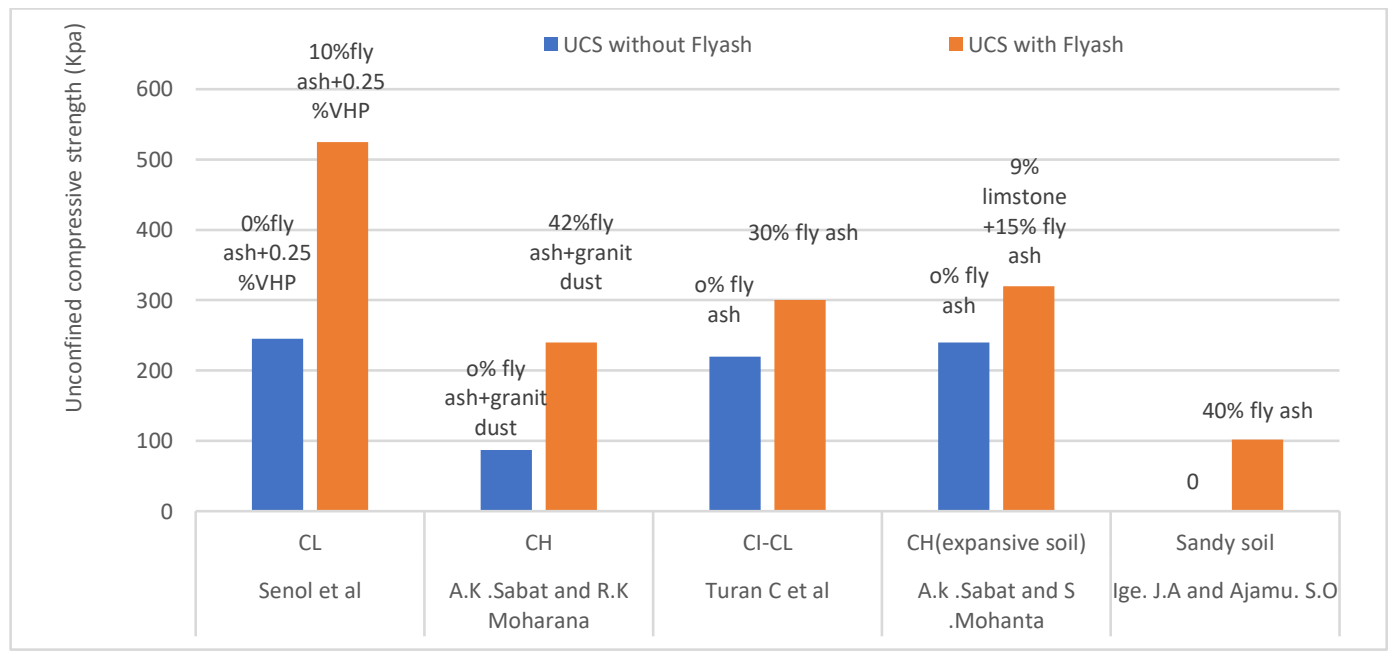

Figure (8): CBR values respected to different researchers with and without fly ash and other materials.

\section{Ground Granulated Blast Furnace Slag}

Yi et al. [43] used an industry by-product, carbide slag (CS), to activate another industry by-product, ground granulated blast furnace slag (GGBS) to enhance soft clay in comparison to Portland cement (PC). The optimum CS content for the CS-GGBS stabilized clay was $4 \%-6 \%$, varying slightly with curing age and GGBS content. The mixtures of clay- CS-GGBS exhibited higher UCS values when compared to the mixtures of clay-PC (more than twice). The following hydration products were detected for clay- CS-GGBS mixtures: "Calcium Aluminate Hydrates", (CAH); "Alumino Ferrite Monosulfate", (AFM); and "Calcium Silicate Hydrates", (CSH).

Al- Khafaji et al. [44] investigated the effect of GGBS (ground granulated blast furnace slag) on the physical and engineering properties of the soft soil (type CI). GGBS was added in various percentages (3, 6, 9 and $12 \%)$. The results indicated an increase in the MDD maximum dry density increased and decrease in the OMC optimum moisture content with increase GGBS content up to around $9 \%$, after that, at $12 \%$ the MDD and OMC gave reversed trend. In terms of Atterberg limits, the liquid limit decreased, the plastic limit increased and the plasticity index decreased with increase GGBS content. Based on the UCS tests, the strength indicator increased up to $80 \%$ at the optimum amount of GGBS ( $6 \%)$.

Padmaraj and Chandrakaran [45] tested the effect of Ground Granulated Blast furnace Slag (GGBS) -lime mixtures in the stabilization of soft soil(CI) to use as subgrade soil. The percentages added were (5-10-15$20 \%$ ) of weight soils. A significant increase in UCS and $\mathrm{CBR}$ value and reduction in the plasticity characteristics were observed when the GGBS content reached 10 percent. The strength improvement is further enhanced when 5 percent of lime is added as an activator.

Gonawala et al. [46] used the Electric Arc Furnaces (EAF) slag and Ground Granulated Blast Furnace Slag (GGBFS) in base/sub-base layer of Flexible Pavement. This material has an advantage in waste utilization by contributing to sustainability. The GGBFS 
proportions were taken $5 \%, 10 \%, 15 \%$ and $20 \%$ of the total dry weight. EAF slag $+15 \%$ GGBFS satisfied the strength criteria for Rural Road. The OMC and MDD increase in the proportion of GGBFS. The UCS value of EAF Slag + 15\% GGBFS indicated satisfy for the optimum mix as Rural Road.

\section{Bio-Fuel Co-Product}

Ceylan et al. [47] investigated the use of lignincontaining biofuel coproduct in pavement soil stabilization. Biofuel coproducts improve the strength of the Iowa Class 10 soil classified to CL or A-6(8). The result of this study showed that the UCS of coproducttreated soil samples increased with the increase in the content of co-products, Atterberg limits and optimum moisture content increased while maximum density decreased.

Ceylan et al.[48] utilized the sustainable material known ( Bio-fuel Co-Product A and B ) Containing Lignin in geotechnical engineering practices to improve roadbed strength and engineering properties.

The optimum is proportional to Biofuel Co-Product A $(25 \%$ lignin and up to $25 \%$ water with a $\mathrm{pH}$ value of 2.2) and Biofuel Co-Product B (5\% lignin, 50\% hemicellulose, 20\% cellulose, and other components). BCP demonstrated a significant amendment results to stabilize clayey soils as improving the durability, efficiency, economy, environmental impact, UCS increased with $12 \%$ of co-products. The co-product B increased the plasticity of soils as a result of arising in the liquid limit and plastic limit values.

For reduction of soil stabilization costs, utilization of lignin-based BCPs (biofuel co-products) as an alternative to stabilize pavement subgrade soil has been investigating by Uzer [49]. The optimum dosage was $12 \%$ (BCP). Four types of soils have been collected from Iowa, USA (SC, CL-ML with fines 62.5\%, CL-ML with fines $53.1 \%$, ML). The results of this study showed that the shear strength values increased up to two times for all soil types.

\section{Brick Kiln Dust}

Bhavsar and Patel [50] resolved the problem of swelling and shrinkage for black cotton soil by replacing the soil by stabilizing agents such as brick. The proportion of blending was $50 \%$ of black cotton soil and $50 \%$ brick dust. The addition of $50 \%$ brick dust leads to increase maximum dry density by $13.27 \%$ where optimum moisture content reduced by $6.39 \%$ as compare to black cotton soil. With Brick Dust 50\% of its dry weight, swelling and shrinkage behavior of expansive soil has been mitigated.

Incorporated of brick kiln dust with fly ash have been studied by Wanare [51], this mixture used as amelioration of geotechnical properties for black cotton soil. The percentages of brick kiln dust and fly ash were $(10 \%, 20 \%, 30 \%$ and $40 \%)$. The effectiveness of fly ash with soil higher than brick kiln dust with soil , specifically liquid limit and plastic limit, on the other side the MDD is constant for all of them while OMC was found to be different in the mixture of soil brick kiln dust and fly ash.
Al-Baidhani and Al-Taie [52] presented a review around brick waste in the stabilization of expansive soil. The optimum content was varied from 40 to $50 \%$. Brick waste considered successful waste in reducing the engineering problems of this soil. MDD decreased with the addition of brick waste.

\section{Ceramic Dust}

The effect of waste ceramic dust as a stabilizer of expansive soil has been investigated by Sabat, Sabat and Boss[53,54]. Sabat used ceramic dust from 0 to $30 \%$ at an increment of $5 \%$. Ceramic dust up to $30 \%$ can be used in strengthening the subgrade of flexible pavements. At 30\% ceramic dust, the classification of the soil changed from $\mathrm{CH}$ to $\mathrm{CL}$, however, MDD increased and OMC decreasing with an increase in the content of ceramic dust. At $30 \%$ ceramic dust, there is a $150 \%$ increase in soaked CBR value as compared to untreated soil. Sabat and Boss investigated the effects of ceramic dust on compaction characteristics.

The optimum dosages of fly ash, lime and ceramic dust were $10 \%, 5 \%, 35 \%$ respectively with improvement in strength, durability and swelling.

James and Pandian [55] investigated the addition of ceramic dust to cement then, this mixture used as a stabilizer of $\mathrm{CH}$ soil. The early gain strength has been discussed and recorded a noticeable performance at a higher ceramic dust content.

James and Pandian [56] studied the free lime contents. They were amended with various amounts of ceramic dust to stabilize cohesive soil. The optimal dosage of CD to lime stabilization resulted in (12-14) \% gain in strength of the stabilized soil. The CD amendment of lime stabilization resulted in a further reduction in plasticity and swell-shrink nature of the stabilized soil. CD was able to enhance the strength of the lime stabilized soil.

\section{Sawdust Ash and Wood Ash}

Supancic and Obernberger [57] utilized wood ashes as a binder for the base road layer. Ash from grate furnace had $\mathrm{CaO}$ higher than lime, therefore, it is able to use as binding particles in the stabilization of soils.

Oluremi et al. [58] treated lateritic soil of low plasticity with up to $10 \%$ waste wood ash (WWA) to assess the volumetric shrinkage of the mixture for use as a liner material. The addition of waste wood ash contributed to reducing the volumetric shrinkage strain of the treated soil. The advantage of additive waste wood ash $10 \%$ on lateritic soil contributed to preventing desiccation. As a result, the cracking occurrence reduced that lead to low hydraulic conductivity.

Ezekiel et al.[59] used Sawdust Ash (SDA) and Palm Kernel Shell Ash (PKSA) on Granular soil materials and Silt - Clay soil materials. The additives were mixed with the soil samples in proportions of $2 \%$, $4 \%, 6 \%$ and $8 \%$. The increment in MDD values as the contents of the additive increase is likely to make the soil suitable for subgrade, subbase and base course. The presence of the additives increases the MDD of the soil which was higher in PKSA than in SDA. The additives 
were reducing the environmental hazard issues arising from the disposal of the wastes.

\section{$\underline{\text { Stone Dust }}$}

Suresh et al. [60] added both optimum percentages of stone dust $(3 \%)$ and fibers $(0.6 \%)$ to the Black Cotton Soil for improving the strength characteristics of subgrade. The results of this study demonstrated an increase in unconfined compressive strength and CBR soaked with the addition of stone dust and fibers while each MDD and OMC decreased.

Dixit and Patil [61] utilized stone dust to improve the engineering properties of expansive soils and can be considered as a good sub base material when used as embankment roads. The percentage of stone dust in the range of 0 to $60 \%$ by weight of soil, increment $10 \%$. The MDD increased and OMC decreased at the stone dust ratio increased as well as the improvement ratio of CBR increased. Also, the reuse of this waste material is economically advantageous and does not bring any environmental hazards.

Mishra et al. [62] demonstrated an economical solution by mechanical stabilization of the subgrade soil with stabilizers such as a coarse aggregate of $10 \mathrm{~mm}$ size and stone dust. The experimental study carried out on three types of fine-grained soil (CL-ML, CL and ML). The study revealed that on the addition of the stabilizers with subgrade soil, the CBR value and MDD increased while OMC decreased. The dosages of these additives were $(10 \%, 20 \%$ and $30 \%$ by mass of dry soil) and (10\% and $20 \%$ by mass of dry soil) for stone dust and $10 \mathrm{~mm}$ size coarse aggregates respectively. Based on $10 \%$ stone dust $+20 \%$ coarse aggregates, the CBR value of the soil improved.

\section{Crushed Tiles}

Liquefaction occurrence for Many sandy soils due to the earthquake in Japan has been studied by Yukihiro et al. [63]. The objectives focused on using the material property of the crushed tile to reduce the liquefaction of the soil. As a result, both angle of internal friction and the coefficient of permeability achieved high value.

Al-Bared and Marto [64] used two different sizes of recycled blended tiles (RBT), 0.063, and $0.15 \mathrm{~mm}$ diameter to stabilize marine clay. These materials considered as environmental-friendly, cost-effective and sustainable stabilizers. RBT for both sizes was added and tested in four different percentages (i.e. 10, 20, 30 and $40 \%$ of the dry weight of soil). MDD increased while OMC decreased due to the RBT reduced the attraction of water molecules. The optimum value of RBT was 30\% and further increment of RBT resulted in a mitigation of MDD. At 40\% RBT, MDD was dropped slightly for $0.063 \mathrm{~mm}$ RBT, while MDD remained steady constant for $0.15 \mathrm{~mm}$ RBT which, in turn, the last can be more effective. However, both sizes considered a good stabilizer compared with the untreated marine clay.

Muralidharan et al. [65] utilized varying percentages of vitrified tiles waste powder with calcium hydroxide to enhance $(\mathrm{CH})$ soils. The different percentages of tiles waste and calcium hydroxide $(5+2.5 \%, 10+5 \%$, $15+7.5 \%, 20+10 \%$ ) were mixed with soil samples. The results have been conjugated and recorded a noticeable performed. The L.L and P.L of the soil decreased while MDD, CBR value and shear strength increased up to $15 \%$ of vitrified tile powder and $10 \%$ of $\mathrm{Ca}(\mathrm{OH}) 2$ and beyond this ratio the results have been taken a reverse trend. As a result, the classification soil changed from clay $(\mathrm{CH})$ to silt $(\mathrm{M})$.

\section{2-Agriculture Waste Rice Husk Ash}

Basha et al. [66] used rice husk ash and cement to stabilize soils and evaluate some soil properties such as plasticity, compaction, and strength and X-ray diffraction. It was found the plasticity of the treated soils was reduced. Compaction test results showed that soil samples with any percentage of rice husk and cement have lower maximum dry density associated with higher optimum moisture content compared with untreated soil samples

Vakili et al. [67] used the ZELIAC as a new stabilizer to treat the dispersive clay (the soil was high plasticity clay or $\mathrm{CH}$ ). It consists of zeolite, activated carbon, limestone, rice husk ash, and Portland cement. ZELIAC is non-hazardous and environmentally friendly which renders it preferable over other stabilizers such as lime or cement. the ZELIAC were 2, 4, 6, 8 and 10\% of the soil dry mass. the OMC increased and MDD decreased with increasing ZELIAC content up to $8 \%$. The decrease in the MDD can be associated with the lower specific gravity of solid (Gs). At 8\% ZELIAC content the compressibility characteristics of the dispersive soil were improved and reduction in plasticity.

Kennedy et al. [68] investigated waste materials (viz., fly ash and rice husk ash) which could be defined as "sustainable materials for enhancing properties of the Expansive soils . The optimum ratio of RHA was 4\% from the soil. Soil replaced with $4 \%$ RHA-4\%Fly ash (class $\mathrm{C}$ or F) $-4 \%$ Lime mix, improved the properties of soil . Unconfined Compressive Strength (UCS) is increased with RHA content. This new sustainable geomaterial is lower cost and can be used as sub-base course for pavements

\section{Bagasse Ash}

Bagasse is a solid waste material. It is extracted from the cane sugar when this waste is burned then, ash produced called bagasse. Utilization of agricultural and industrial waste to reduce the swelling percentage and improvement of the strength of black cotton soil have been studied by Dalal et al. [69]. Firstly, bagasse ash and granulated blast slag (GGBS) were combined, secondly, the wood powder was added. Both of these additives increase the unconfined compressive strength and CBR values. GGBS and bagasse ash contributed more towards strength and wood powder contributed more towards swelling control.

Hatmoko and Suryadharma [70] investigated the mechanical behavior of bagasse ash stabilized organic soil. The soil was mixed with 10, 20 and 30\% bagasse ash. The results indicate that the unconfined 
compression strength of stabilized soil improves slightly. Based on the addition of bagasse to the organic soil, the UCS does not significantly improve therefore that required the addition of 6,8 , and $10 \%$ calcium carbide residue (CCR) to get better strength results.

\section{Coconut Shell Ash}

Hamza and Paul [71] studied the effects of polyurethane for clay soil and coconut charcoal ash for expansive soil. It was found that $0.5 \%$ of Polyurethane improved the shear strength of marine clay by more than $230 \%$. The coconut shell powder (CSP) (0\% 3\% 6\% 9\% and $12 \%)$ and lime (3\% 6\% and $9 \%$ ) increase in MDD for soil sample treated with CSP and lime. The compressive strength of the expensive soil increased by $228 \%$ when treated with coconut shell powder and lime.

\section{3- Domestic Waste Waste Tire}

Akbulut et al. [72] investigated the influence of waste fiber materials such as scrap tire rubber in order to modify three clayey soil $(\mathrm{CH})$. The dosage of scrap tire rubber were $1,2,3,4$, and $5 \%$ by weight of soil. The UCS increased with adding tire rubber fiber content up to $2 \%$ of $10 \mathrm{~mm}$ length then decreased. At the same time, each cohesion and internal friction values increased.

Kennedy et al. [68] investigated waste materials Ground Shredded Rubber Tire (GSRT) to improve the sandy soil. The addition of Ground Shredded Rubber Tire (GSRT) to fine sand contributed to decreasing the dry density while the angle of internal friction increased in both loose and dense states. The coefficient of permeability (drainage characteristics) increases in both dense and loose states when the GSRT was added. The usage of GSRT in geotechnical infrastructure is a wise option of achieving sustainable development.

Prasad et al. [73] used different reinforcement materials in the gravel/fly ash subbase courses laid on expansive soil subgrade. It was observed from the laboratory test results of direct shear and CBR, that the optimum percentage of waste plastics and waste tire rubber are equal to $0.3 \%$ and $5 \%$ for gravel subbase material and $0.4 \%$ and $6.0 \%$ for fly ash subbase materials.

Kirubakaran and Dinesh [74] studied the improvement of bearing capacities of the clay soil using waste tyre rubber. The shredded tyre material used is of size 4- $5 \mathrm{~mm}$ in length. The shreds have a thickness ranging from $2-3 \mathrm{~mm}$. Using waste tyre rubber is most effective in earthquake resistant structures. The range of waste tyre percentages about (3-9) increment $1 \%$.

Hussein et al. [7] presented assessment two granular additives: granulated tire rubber, silica sand on stabilization of soil. The swelling of soil specimens contained sand is less than that contained GTR.

\section{Egg Shell}

The assessment potential of egg-shell powder as a stabilizer of clayey soil have been investigated by Walia et al, Anoop et al, and Jijo [75-77] respectively. This stabilization method is economical and eco-friendly to reduce the disposal problems of egg shell. Walia et al replaced the traditional materials with ESP (egg shell powder) and SD (stone dust). ESP series of percentages $2,4,6,8,12,16,20 \%$ and stone dust 10, 20, $30 \%$ were added by weight of samples. CBR value maximizes from 3.94 to 7.90 with rise in the percentage of ESP from $2 \%$ to $20 \%$. Anoop et al used egg shell powder substitute lime. The egg-shell powder was introduced in quantities of $0.5 \%, 1 \%, 1.5 \%$ and $2 \%$ of the weight of soft clayey soil. This material demonstrated much better Strength properties with $25 \%$ replacement of lime by egg shell powder then used the result of mix to treat the soft clayey soil. Eventually, Jijo utilized the (ESA) as an auxiliary addendum to lime in the stabilization of expansive soil. The addition of ESA resulted in a rise in the strength of lime stabilized soil and mitigate in the plasticity of lime stabilized. The optimum (ESA) content is $2 \%$ which is producing a strength gain of lime about $24.43 \%$ at 28 days of curing.

\section{Glass Cullet}

A number of researchers have discovered the usage of GC to amend the particle size distribution of the resulting soil such as kaolin clay and natural sandy gravel by PennDOT [78], kaolin and bentonite mix by Malasavage et al. [79], river dredged material by Grubb et al. $[80,81]$. The dosages were $(10,20,35,50 \%),(20$, $40,50,60,80 \%),(20,40,50,60,80 \%)$ respectively. GC was found in two groups: fines, in which a significant percentage of the soil is passing from sieve $0.075 \mathrm{~mm}$ (such as silts and clays), and granular materials, in which a significant percentage is retained on sieve $0.075 \mathrm{~mm}$ (sand and gravel).They were stated that the effect of adding GC is negligible in well-graded soils. However, when the soil is poorly graded, the addition of GC would fill the missing size fraction of the soil. As a result amending the particle size distribution of the resulting soil.

An increase in the content of GC results reduction around $10 \%-20 \%$ in L.L, P.L and P.I respected to Basari [82], Eberemu et al. [83], Fauzi et al. [84], Grubb et al. [80], Malasavage et al. [79].

The addition of GC can produce a significant minimal on the OMC, While Maximal on the MDD of fine-grained soils. This case has been studied by, Disfani et al. [85-87], Grubb et al. [80], PennDOT [78] and PennDOT [88] as well as recorded a pronounced effect when the GC content is more than $35 \%$.

The effects of GC on both cohesion(C) and angle of friction ( $($ ) have been examined by Dames and Moore [89] in gravelly sand and crushed rock, PennDOT [78] in kaolin, sandy silt and silty sand, Grubb et al. [81] in dredged materials, Mavroulidou and Ahmed [90] in natural sand, Basari [82] in the sand and Eberemu et al. [83] in laterite. The results of these studies were a reductionin cohesion. However, if the soil has low plasticity, such as quarry fines, GC has little effect on its cohesion .on the other side increases $(\varnothing)$ of kaolin, laterite, silty sand and sandy silt, while decreases $(\varnothing)$ of quarry fines and no significant effect on $(\varnothing)$ of sand or a mixture of sand and gravel. 


\section{Plastic Bottles}

Consoli et al. [91] utilized randomly distributed polyethylene terephthalate fiber, obtained from recycled waste plastic bottles, alone or combined with rapid hardening Portland cement to improve the engineering behavior of a uniform fine sand. The plastic bottles as a fiber content (up to $0.9 \mathrm{wt} \%$ ), fiber length (up to 36 $\mathrm{mm}$ ), cement content (from 0 to 7 wt \%). The unconfined compressive strength and the tensile strength of the cemented sand were significantly increased by fiber reinforcement.

Peddaiah et al. [92] made a study on the behavior and use of waste plastic in silty sand soil improvement. The results showed that, plastic can be used as an effective stabilizer so as to encounter a waste disposal problem as well as an economical solution for stabilizing weak soils. Plastic reinforced soil behaves like a fiber reinforced soil. The percentages of plastic bottles were $(0.2,0.4,0.6$, and $0.8 \%)$ for $(15 \mathrm{~mm} \times 15 \mathrm{~mm})$ size of plastic strips. The results of this study's maximum dry unit weight (MDD) are observed to be maximum at 0.4\% plastic content while OMC values show just an opposite trend of MDD values for plastic reinforced soil. Shear strength parameters exhibited the highest improvement at $0.4 \%$ of plastic content. The addition of plastic in percentages increases the $\mathrm{CBR}$ value.

Rashmi et al [93] utilized the waste of plastic bottles and other plastic to improve the properties of black cotton soil (expansive soils). This material is friendly environmental and economical. The various proportions of plastic waste $\%$ by weight varying by $0.5 \% 1.0 \%$ and $1.5 \%$ The black cotton soil was added and the optimal percentage of plastic strips was determined by the CBR values. $2 \%, 4 \%, 6 \%, 8 \%$ and $10 \%$ of cement is used as a stabilizer by weight of soil.

Al-Taie et al. [8] make a study on the use of powder waste plastic in poorly sand soil improvement. They were showed that, powder plastic can be used as an effective stabilizer for poorly graded sand. This is giving an encounter waste disposal problem as well as an economical solution for stabilizing poorly graded sandy soils.

\section{Fibers}

Changizi and Haddad [94] investigated the effect of recycled polyester fiber, produced from polyethylene (PET) bottles, in combination with nano-SiO2 as a new stabilizer to improve the mechanical properties of soft clay soil. Three different combinations of fiber-soil ratios ranging between $0.1 \%$ and $0.5 \%$ as well as three different combinations of nano-soil ratios ranging between $0.5 \%$ and $1 \%$ are used. The results indicated that a reduction in failure strain and increases the shear strength, UCS, elastic modulus, angle of internal friction, cohesion of soil and the interlocking force between fiber surface and soil particles with an increase in the nano -Sio2 in the other hand the increase in nano-SiO2 contents contributes to the creation of tensile cracks in the treated specimens.

Kennedy et al. [95] investigated the Irvinga Gabonesis fibre, popularly called Bush mango with lime to improve the soft clay soils. irvinga gabonesis fibre + lime with $0.25 \%+2.5 \%, 0.5 \%+5.0 \%, 0.75 \%+7.5 \%$ and $1.0 \%+10 \%$ combined ratio to soils. Stabilized soils result of compaction test confirmed increased values in both maximum dry density and optimum moisture content with inclusion percentages ratio increase. Unconfined compressive strength test results showed increased values with additives percentages ratio increase, the plastic index decreased with an increase in percentage ratio additives. Compaction test results proved increased values in both MDD and OMC with increased additives. UCS increased values with additives percentages ratio increase. The values of the plastic index decreased with an increase in percentage ratio additives.

Bordoloi et al. [96] Explored the usage of sustainable materials in the form of natural fibers for reinforcing and improving the (ML) subgrade strength of pavements. In order to improve the strength as well as increasing the working life of such natural fibers ((jute, and water hyacinth and coir), using chemically coat the natural fiber surface with nanoparticles of ferric hydroxide and aluminum hydroxide. The results demonstrate the efficacy of using chemically altered natural fiber in increasing the subgrade strength of embankment material as a sustainable infrastructure tool. The treatment further decreased the moisture absorption capacity of the fibers thus increasing their work life.

\section{4-Mineral Waste Zinc Waste}

Poulose and Vasudevan [97] investigated the use of Jarofix (a waste material produced during the extraction of zinc ore) as random reinforcing material with clayey soil $(\mathrm{CH})$ to improve engineering behavior. Specimens were prepared at different percentages of Jarofix viz. $0.5 \%, 1 \%, 1.5 \%, 2 \%, 2.5 \%$ and $3 \%$. Deviatoric stress at failure is increasing as the percentage of jarofix content increases and the maximum occurs at the $2 \%$ of jarofix addition. Undrained cohesion, angle of internal friction and young's modulus also increases. Curing has a very positive result on the shear strength characteristics of the soil. Up to 3 days curing provide greater improvement in shear strength characteristics. The strength gain may be due to pozzolanic reaction, cation exchange and strength gaining compounds formed within the soil Jarofix mixture in the presence of water due to the chemical

\section{Marble Dust}

Marble dust had been used as an additive material in three specimens of clay soil (CH, CL, and CL) by Zorluer and Muratoglu [98]. The specimens were blended with waste marble dust at $5 \%, 10 \%$ and $15 \%$. The results obtained from this study included both of swelling index and consolidation index of specimens were decreased as well as void ratio decreases. As a result, consolidation settlement reduced.

Saygili [99] utilized waste marble dust in stabilizing problematic soils (especially swelling clays) consist of Kaolinite and bentonite clays. The marble dust addition ratios which have been studied were $0 \%, 5 \%, 10 \%, 20$ 
$\%$ and $30 \%$ by weight. The obtained results of this study were shown the optimum moisture content and swelling potential decreased while Maximum dry unit weight and unconfined compressive strength increased with a rising percentage of marble dust addition. SEM images show morphological changes when clay samples are treated with marble dust displaying a more compact structure with fewer pores and pores are filled with cementitious products.

The usage of marble dust for silty soil (MH) stabilization has been investigated by Yilmaz and Yurdakul [100]. Geotechnical properties, such as Atterberg limits, compaction, unconfined compressive strength were determined. The percentages of marble dust were $(5 \%, 10 \%, 15 \%, 20 \%, 25 \%, 30 \%, 35 \%$, and $40 \%$ ). The results showed that the improvement of high plasticity silty soil was noted with both of OMC and UCS with the increasing marble dust ratio.

Priyanka and Rao [101] utilized marble dust as a stabilizer to treat expansive soil. Laboratory tests conducted on the black cotton soil mixed with various percentages $(0,5,10,15$ and $20 \%)$ of marble dust (MD). The results showed an increase of Maximum dry density (MDD) and a decrease of Optimum Moisture Content (OMC) values with the increase of MD percentage. The immediate strength of black cotton soil samples increased with an increase of marble dust content up to $15 \%$, after that the trend of strength decrement from $15 \%$ marble dust to $20 \%$ marble dust in soil samples.

Neeladharan et al. [102] improved the load bearing capacity of clay soil $(\mathrm{CH})$. The different percentage of $5 \%, 10 \%, 15 \%$ and $20 \%$ of marble dust and $2.5 \%, 5 \%$, $7.5 \%$ and $10 \%$ of sodium silicate has been added and recorded alteration results. A ratio of marble dust 15\% and $\mathrm{Na}_{2} \mathrm{SiO}_{3} 10 \%$ (optimum percentages), the soil changed from $\mathrm{CH}$ to ML, L.L and P.L of the soil decreased, The MDD increased while OMC decreased and The CBR value has increased.

\section{Silica Fume}

Akbulut and Saglamer [103] investigated the most effective mixture of silica fume, fly ash, clay and comparable with cement, then using as filling materials to enhance granular soil (SP). The experimental test included grouting these materials in a plastic cylindrical mold of the soil .The capable $10 \%$ and $20 \%$ of SF to reduce the hydraulic conductivity were more efficiently than cement while the $50 \%, 80 \%, 100 \%$ of clay decreased the permeability and $10 \%$ of fly ash revealed an indicator performance to decrease permeability consequentially for all percentages the shear strength increased with added these materials.

The effect of adding silica fume to improve the engineering properties of clayey soil has been studied by Kalkan and Akbulut [104], Kalkan [105] . Kalkan and Akbulut found the adding of silica fume on soil resulted in low values in permeability and swelling pressure and significantly high compressive strength. While Kalkan added series percentages $(10,20,30,40,50 \%)$ of silica fume on the soil. The results included a drop in the expansion of dryness cracks on the surface soils as well as the compressibility and swelling behavior decreased.

Khaled [106] examined the suitability of silica fume as a stabilization material improve clayey soils. The amount of silica fume added series percentages. The results show that silica fume decreases the development of desiccation cracks on the surface of compacted samples by the gyratory compactor, the optimum moisture content values increased and the maximum dry unit weight values decreased.

Saygili and Dayan [107] used silica fume and fiber to improve the compressive strength values and enhanced the freeze-thaw of the lime rich kaolinite durability which classified as (CL) soils. A Silica fume particle reacted with the lime rich kaolinite and through hydration reactions, $\mathrm{CSH}$ gel products were formed, which surrounded the kaolinite particles. Voids of the modified samples were filled with the CSH gel Fibers improved the friction resistance, the interlocking effect was created by cementation reactions between lime stabilized soil. fiber content varied between $0.25 \%$ to $1 \%$ and silica fume content varied between $2.5 \%$ to $10 \%$ by dry weight of kaolinite clay. The obtained results demonstrated that the characteristic of the modified clay soils for stress-strain curves changed and shifted from ductile to brittle.

\section{Conclusions}

Sustainable materials are environmental eco-friendly materials used as a stabilizer to mitigate the negative effects for soil through the occurrence of pozzolanic and chemical reactions lead to bind particles of soil by cementitious sustainability. A review of these materials was presented and discussed in this paper. It was demonstrated that:

1- The range for dosages of different additives was varied widely, for industrial waste such as CKD, red mud, fly ash, GGBS, brick kiln dust, ceramic dust, Sawdust ash, bio-fuel co-product, stone dust, crushed tiles, these dosages ranged from (2\%$50 \%$ ). While these dosages for agricultural waste like rice husk ash ,bagasse ash and coconut shell ash ranged from (4\%-30\%). The dosages of domestic waste such as waste tire, egg shell, plastic bottles, fibers ranged from $(2 \%-8 \%)$ except glass cullet which reached more than $10 \%$, mineral waste dosages such as zinc waste, marble dust and silica fume ranged from $(2 \%-40 \%)$.

2- In general, the influence of addition sustainable materials on Atterberg limits have been reviewed and noticed different behavior according to types of soil and stabilizer. However, most of these materials led to reduce in values of Atterbreg limits (L.L ,P.L ,PI) excepted bio-fuel co product,in which the ( LL,PL, PI) increased when added it .

3- In most cases, the effect of added sustainable materials on potential swelling has been discussed and reported an observation performance to reduce it. However, the proportions of these materials were more effective in potential swelling. 
4- A few numbers of researchers investigated the effect of sustainable materials on permeability materials.

5- The amount of improvement soil researches that focused on fine grain soil has been studied by many researchers more than coarse grain soils.

6- The compaction characteristics of these soils (MDD and $\mathrm{OMC}$ ) was varied according to the type of soils and sustainable materials. MDD and OMC sometimes decreased and increased respectively, however, their performance may follow different approaches. The main objectives of adding these materials should be to make the structure of soil more flocculated and agglomeration especially, clay particles.

7- Based on the percentage and type of sustainable materials used, the California bearing ratio and unconfined compressive strength of the soils were improved when these soils treated with these additions. Due to the limited effect of Egg shell on soil, the egg shell mixed with lime to improve it .

8- Industrial waste by a product like CKD, GGBS, red mud,... revealed more efficiently to improve the soil when compared with other groups

9- Sustainable materials are economy, friendly environment through mitigation of the adverse effects such as health hazards on humans and problems of storages.

\section{References}

[1] M. Fatani, A. Alzahrani "Scoria stabilized soils," Proc., 1st Geotech. Engrg. Conference, pp.44-52, 1991.

[2] V. Petrenko, O. Tiutkin, I. Sviatk, "Study of the effect of soil cement elements when stabilizing roadbed model in laboratory conditions," Science and Transport Progress. Bulletin of Dnipropetrovsk National University of Railway Transport pp.112-119, 2017.

[3] B. Liang, T. Dong, Y. Mei, J. Pan, "Test research on influence of admixture agent on engineering characteristics of red sandstone roadbed filling in dongchang expressway," $3^{\text {rd }}$ International Conferenece on energy materials and environment engineering, 2017, IOP Conf. Series: Earth and Environmental Science, vol. 61, pp.1-8, 2017. doi :10.1088/1755-1315/61/1/012103. [4] A. Sharo,Y. Alhowaidi, M.Al-Tawaha, "Improving properties of expansive soil using cement, quick lime and cement-lime blend," Internasional review of civil engineering (I.RE.C.E.), vol.10, no.2, pp.94-103, 2019.

[5] A. Al-Taie, Y. Al-Shakarchi, "Dune Soils of Mesopotamian Plain as geotechnical construction material," LAP LAMBERT Academic Publishing, 2016.

[6] A. Al-Taie, Y. Al-Shakarchi, "Shear Strength, collapsibility and compressibility characteristics of compacted Baiji dune soils," Journal of Engineering Science and Technology, School of Engineering, Taylor's University, vol.12, no .3, pp.767 - 779, 2017.

[7] A. Hussein, A. Ali, A. Al-Taie, "A Review on Stabilization of Expansive Soil Using Different
Methods" Journal of Geotechnical Engineering, vol. 6, no. 3, pp. 32-40, 2019.

[8] A. Al-Taie, A. Al-Obaidi, M. Alzuhairi, "Utilization of Depolymerized Recycled Polyethylene Terephthalate in Improving Poorly Graded Soil," Transportation Infrastructure Geotechnology, vol. 7, 2020.

[9] N. Cristelo, S. Glendinning, L. Fernandes, A. pinto, "Effects of alkaline activated fly ash and Portland cement on soft soil stabilization," Acta Geotech., vol. 8, pp. 395-405, 2013. https://doi.org/10.1007/s11440012-0200-9.

[10] S. Rios, N. Cristelo, A. Fonseca,C. Ferreira, "Structural performance of alkali -activited soil ash versus soil cement," Journal of materiales in civil engineering, vol.28,no.2, pp.1-30, 2016.

[11] J. Han, "Principles and Practice of ground improvement” John Wily ,Sons, Hoboken, New Jersey, Canada, 2015.

[12] A. Al-Taie, B. Albusoda, S. Alabdullah, A. Dabdab, "An Experimental Study on Leaching in Gypseous Soil Subjected to Triaxial Loading," Geotech Geol Eng , vol. 37, no. 6, pp. 5199-5210, https://doi.org/10.1007/s10706-019-00974-2, 2019.

[13] D. Al-Jeznawi, M. Sanchez, A. Al-Taie, M. Zielinski, "Experimental studies on curling development of artificial soils," Journal of Rock Mechanics and Geotechnical Engineering, vol. 11 no. 6, pp.1264-1273, 2019.

[14] B. Kermani, S. Stoffels, M. Xiao, T. Qiu "Experimental Simulation and Quantification of Migration of Subgrade Soil into Subbase under Rigid Pavement Using Model Mobile Load Simulator," Journal of Transportation Engineering, Part B: Pavements, vol. 144, no. 4, pp. 1-14, 2018.

[15] K. Tiwari, S. Sahil Khandelwal, A. Jatale, "Performance, Problems and Remedial Measures for the Structures Constructed on Expansive Soil in Malwa Region, India," International Journal of Emerging Technology and Advanced Engineering Website: www.ijetae.com, Certified Journal, vol.2, no.12, 2012.

[16] Z. Baghdadi, M. Fatani, N. Sabban, "Soil modification by cement kiln dust," journal of materials on civil engineering, vol.7, pp.218-222, 1995.

[17] G. Miller, S. Azad, "Influence of soil type on stabilization with cement kiln dust" Construction and Building Materials, vol.14, pp.89-97, 2000.

[18] G. Miller, M. Zaman, "Field and Laboratory Evaluation of Cement Kiln Dust as a Soil Stabilizer," Transportation Research Record, no. 1714, pp. 25-32, 2000. http://dx.doi.org/10.3141/1714-04.

[19] R. Parsons, E. Kneebone, "Use of cement Kiln Dust for the stabilization of soils," Geotechnical engineering for the transportation projects, GeoTrans 200, pp. 124-1131, 2004. https://doi.org/10.1061/40744(154)101.

[20] A. Amadi, "Enhancing durability of quarry fines modified black cotton soil subgrade with cement kiln dust stabilization," Transportation Geotechnics, vol. 1, no. 1, pp. 55-61, 2014. 
[21] I. Jimoh, A. Amadi, E. Ogunbod "Strength characteristics of modified black clay subgrade stabilized with cement kiln dust," Innov. Infrastruct. Solut. Vol. 3, pp. 55, 2018. https://doi.org/10.1007/s41062-0180154-3.

[22] K. Hossain, M. ASCE, "Stabilized Soils Incorporating Combinations of Rice Husk Ash and Cement Kiln Dust," Journal Of Materials In Civil Engineering (C) ASCE, vol.23, no.9, pp.1320-1327, 2011. [23] A. Al-Homidy ,M. Dahim , A. ABD EI Aal, "Improvement of geotechnical properties of sabkha soil utilizing cement kiln dust," Journal of Rock Mechanics and Geotechnical Engineering, vol.9, no.4, pp.749-760, 2017.

[24] S. Cui, J. Wang, X.D Wang, Y. Du, X.P. Wang, "Mechanical behavior and micro-structure of cement kiln dust-stabilized expansive soil," Arabian Journal of Geosciences, vol. 11, no. 17. Pp. 1-8, 2018, 10.1007/s12517-018-3864-0.

[25] A. Mohammadinia, A. Arulrajah, A. Amico, S. Horpibulsuk, "Alkali- activation of fly ash and cement kiln dust mixtuers for stabilization of demolition aggregate," Construction and building materials, vol.186, pp.71-78, 2018.

[26] Z. Mahdi, M. Hasan, H. Jasim, "Assessment of Using Cement Kiln Dust Stabilized Roads Subbase Material," International Journal of Engineering \& Technology, vol. 7, no. (4.20), pp.162-165, 2018.

[27] A. Naseem, W. Mumtaz, F. Jalal, H. Backer, "Stabilization of Expansive Soil Using Tire Rubber Powder And Cement Kiln Dust," Soil Mechanics and Foundation Engineering, vol.56, no.1, pp.54-58, 2019.

[28] V. Shukla, S. Tiwari, "Improvement of pavement soil subgrade by using cement kiln dust," International journal for research in Applied Science \& Engineering Technology (IJRASET), vol.7, pp.23412345, 2019.

[29] A. Almurshedi, "Swelling control of expansive soils using cement dust," IOP conference series: materials science and engineering, pp.1-9, 2019.

[30] A. Al-Baidhani, A. Al-Taie, "Stabilization of Expansive Soils Using Stone Waste Materials: A Review," IJO-International Journal of Mechanical and Civil Engineering, vol.2, no. 7, pp. 1-7, 2019 a.

[31] S. Rimal , R. Poudel , D. Gautam, "Experimental study on properties of natural soils treated with cement kiln dust," Elsevier, Science Direct, Case Studies in Construction Materials, vol. 10, no. e00223, pp. 1-7, 2019.

[32] E. Kalkan, "Utilization of Red Mud as a Stabilization Material for the Preparation of Clay Liners," Engineering Geology, vol. 87, no. (3-4), pp. 220-229. 31, 2006.

[33] I. Kocserha, A. Hamza, R. Geber, "The effects of red mud on clay compounds," IOP Conf. Series: Materials Science and Engineering, vol. 426, pp. 1-7, 2018. doi:10.1088/1757-899X/426/1/012026

[34] G. Sridevi, S. Sahoo, S. Sen, "Stabilization of Expansive Soil with Red Mud and Lime," Ground
Improvement Techniques and Geosynthetics, Lecture Notes in Civil Engineering, vol.14, pp.259-268, 2019.

[35] S. Kolias, V. Kasselouri-Rigopoulou, A. Karahalios, "Stabilization of Clayey Soils with High Calcium Fly Ash and Cement," Cement and Concrete Composites, vol.27, pp.301-313, 2005.

[36] J. Zhang, R. Solis, "fly-ash-stabilized gypsiferous soil as an embankment material," In: Liu H., Deng A., Chu J. (eds) Geotechnical Engineering for Disaster Mitigation and Rehabilitation. Springer, Berlin, Heidelberg, pp.810-814, 2008.

[37] L. Han-bing, L. Chang-yu, W Hai-bin, "Experimental research on the mechanical parameter of fly ash soil," Ninth International Conference of Chinese Transportation Professionals (ICCTP), pp.41-48,2009.

[38] A. Senol, E. Etminan, T. Ozudogru, H. Yildirim, "stabilization of a low plasticity clay soil by alternative materials," Geotechnical Society of Singapore (GeoSS), pp. (271-277), 2012.

[39] A. Sabat, R. Moharana, "Effect of Compaction Energy on Engineering Properties of Fly Ash -Granite Dust Stabilized Expansive Soil," International Journal of Engineering and Technology (IJET), vol.7, no.5, pp.1618-1624, 2015.

[40] C. Turan, G. Russo, N. Consoli, "mechanical properties of calcareous fly ash stabilized soil," EUROCOALASH, Dundee, Scotland, UK, 2019.

[41] A. Ige, S. Ajamu, "Unconfined Compressive Strength Test of A Fly Ash Stabilized Sandy Soil," International Journal of Latest Research in Engineering and Technology (IJLRET), vol.1,no.3, pp.01-11, 2015.

[42] A. Sabat, S. Mohanta, "Performance of limestone dust stabilized expansive soil-fly ash mixes as construction material," International journal of civil engineering and technology (IJCIET), vol.7, no.6, pp.482-488, 2016.

[43] Y. Yi, L. Gu, S. Liu, A. Puppala, "Carbide slag-activated ground granulated blastfurnace slag for soft clay stabilization," Canadian Geotechnical Journal, vol. 52, no. 5, pp. 656-663, 2015. https://doi.org/10.1139/cgj-2014-0007

[44] R. Al-Khafaji, H. Jafer, A. Dulaimi, W. Atherton, Z. Weida, "Soft soil stabilisation using ground granulated blast furnace slag,", The 3rd BUiD Doctoral Research Conference, At British University in Dubai, 2017.

[45] D. Padmaraj, S. Chandrakaran, "stabilisation of soft clay using ground granulated blastfurnace slag and lime,"Sixth Indian Young Geotechnical Engineers Conference 6IYGEC2017, pp. 156-161, 2017.

[46] R. Gonawala, S. Khapre, R. Kumar, K. Chauhan,"Suitability of EAF slag and GGBFS mix as cementitious base/subbase layer for low volume road construction," International Journal of Geotechnical Engineering, $\quad$ pp. (1-7), 2019. https://doi.org/10.1080/19386362.2019.1621458.

[47] H. Ceylan, K. Gopalakrishnan, S. Kim, "Soil stabilization with bioenergy coproduct," Transportation Research Record: Journal of the Transportation Research Board, vol. 2186 no. 1, pp.130-137 2010. 
[48] H. Ceylan, S. Kim, K. Gopalakrishnan, "Sustainable Utilization of Bio-fuel Co-Product in Roadbed Stabilization," Sustainable Bioenergy and Bioproducts, Green Energy and Technology, In: Gopalakrishnan K., van Leeuwen J., Brown R. (eds) Sustainable Bioenergy and Bioproducts. Green Energy and Technology. Springer, London, pp.117-129, 2012. 10.1007/978-1-4471-2324-8_7.

[49] A. Uzer, "Use of biofuel co-product for pavement geo-materials stabilization," The $5^{\text {th }}$ international conference of euro Asia civil engineering forum (EACEF-5), pp.685-691, 2015.

[50] S. Bhavsar, A. Patel, "Analysis of swelling and shrinkage properties of expansive soil using brick dust as a stabilizer," International Journal of Emerging technology and advanced engineering, vol.4, no.12, pp.303-308, 2014.

[51] R. Wanare, "Behavioural Study of Black Cotton Soil with Brick Kiln Dust and Fly Ash," International Journal of Geological and Geotechnical Engineering, vol.4, no.2, pp.8-15, 2018.

[52] A. Al-Baidhani, A. Al-Taie, "Review of brick waste in expansive soil stabilization and other civil engineering applications," Journal of Geotechnical Studies, vol. 4, no. 3, pp. 14-23, 2019 b.

[53] A. Sabat, "Stabilization of Expansive Soil Using Waste Ceramic Dust," EJGE, vol.17, pp.3915-3926, 2012.

[54] A. Sabat, B. Boss, "Strength, Swelling and durability characteristics of fly ash -lime stabilized expansive soil-ceramic dust mixes," International Journal of earth sciences and engineering, pp. 1210-1215, 2014.

[55] J. James, P. Pandian, "A study on the early UCC strength of stabilized soil admixed with industrial waste materials" International Journal of Earth Sciences and Engineering, vol.7, pp.1055-1063, 2014.

[56] J. James, P. Pandian, "Strength and microstructure of micro ceramic dust admixed lime stabilized soil," Revista de la construcción, vol. 17, no. 1, pp.5-22, 2018.

[57] K. Supancic, I. Odernberger, "Wood ash utilization as a binder in soil stabilization for road construction - first results of large-scale tests," Graz, Austria, 2011.

[58] J. Oluremi, A. Eberemu, K. Osinubi, "Volumetric shrinkage of compacted waste wood ash stabilized lateritic soil," Proceedings of the Third International Conference on Engineering and Technology Research, ISBN: 978-2902-58-6, vol. 3, pp.229-239, 2014.

[59] A. Ezekiel, A. Jonathan, "Evaluation of Presence of Sawdust and Palm Kernel Shell Ashes on Geotechnical Properties of Ekiti State Soil'Journal of Multidisciplinary Engineering Science and Technology JMEST, vol.2, no.11, pp.3184-3188, 2015.

[60] K. Suresh, V. Padmavathi, A. Sultana, "Experimental study on stabilization of black cotton soil with stone dust and fibers," Indian Geotechnical Conference, pp 502-506. 2009.
[61] M. Dixit, K. Patil, "Utilization of stone dust to improve the properties of expansive soil", International Journal of Civil Engineering and Technology (IJCIET), vol.7, no.4, pp.440-447, 2016.

[62] S. Mishra, S. Sachdeva, R. Manocha, "Subgrade Soil Stabilization Using Stone Dust and Coarse Aggregate: A Cost Effective Approach," International Journal of Geosynthetics and Ground Engineering, issue 3, pp. 2-11, 2019.

[63] M. Yukihiro, M. Kenichi, Z Feng, "Effectiveness of crashed tile in countermeasure against liquefaction," Int. J. of GEOMATE, vol.7, no.1, pp.1003-1008, 2014 .

[64] M. Al-Bared, A. Marto, "Evaluating the Compaction Behaviour of Soft Marine Clay Stabilized with Two Sizes of Recycled Crushed Tiles," Springer Nature Singapore Pte Ltd. 2019, B. Pradhan (ed.), GCEC 2017, Lecture Notes in Civil Engineering, vol. 9, pp.(1273-1284),2019.

[65] A. Muralidharan, C. Neeladharan,Z. Rahman, M. Kumar , C. Soban, M. Abdullatif "Stabilization of Soil using Vitrified Tiles Waste Powder and Calcium Hydroxide as Binder," Suraj Punj Journal For Multidisciplinary Research, vol.9, pp.75-82, 2019.

[66] E. Basha, R. Hashim, H. Mahmud, A. Muntohar, "Stabilization of Residual Soil with Rice Husk Ash and Cement," Construction Building Material, vol.19, pp.448-453, 2005.

[67] A. Vakili, M. Bin Selamat, H. Bin Abdul Aziz, A. Mojiri, Z. Ahmad, M. Safarzadeh, "Treatment of dispersive clay soil by ZELIAC," Geoderma, vol. 285, no. 1, pp. 270-279, 2017.

[68] C. Kennedy, T. Amgbara, P. Paulinus, "Hybridized Composite Materials Effect on Stabilization of Soft Clay Soils in Niger Delta", Journal of Scientific and Engineering Research, , vol.5,no.10, pp.97-103, 2018.

[69] S. Dalal, R. Patel, P. Dalal, "Effect on Engineering Properties of Black Cotton Soil treated with Agricultural and Industrial waste," Materials Today: ScienceDirect, Proceedings, vol. 4, pp.9640-9644, 2017

[70] J. Hatmoko, H. Suryadharma, "Fundamental factors on the behaviour of bagasse ash stabilized organic soil," SCESCM, vol. 258, 2019, https://doi.org/10.1051/matecconf/201925801019.

[71] M. Hamza, S. Paul, "Effects of Polyurethane and Coconut Charcoal Ash in Soil Stabilization : A Review," , International Journal of Technical Innovation in Modern Engineering \& Science (IJTIMES),(UGC APPROVED), vol.5, no. 4, pp.124-127, 2019.

[72] S. Akbulut, S. Arasan, E. Kalkan, "Modification of clayey soils using scrap tire rubber and synthetic fibers," Science direct, Elsevier, Applied Clay Science, vol. 38, pp.23-32, 2007.

[73] D. Prasad, K. Anjan, R. Prasada, V. Kondayya, "Evaluation of Different Reinforced Subbase on Expansive Soil Subgrade -a Laboratory Model Study," Proceedings of Indian Geotechnical Conference December 15-17, Kochi, no. H-234, pp.457-460, 2011. 
[74] K. Kirubakaran, S. Dinesh, "Stabilization of Soil by Use of Waste Tyre Rubber," International Journal of Innovative Science, Engineering \& Technology, vol.6 no.10, pp. 04018049(1-14), 2019.

[75] B. Walia, G. Singh, H. Singh, "Effect of Egg Shell Powder and Stone Dust on Compaction Characteristics and CBr Value of Clayey Soil," Journal of Environmental Research and Development, vol.5(3), pp.202-208, 2015.

[76] Anoop. S P, Beegom. H, Johnson. J.p, Midhula J, Tharis Muhammed T.N, Prasanth S, "Potential of Egg shell powder as replacement of Lime in soil stabilization," International Journal of Advanced Engineering Research and Science (IJAERS), Vol4, no.8, pp.(86-88), 2017.

[77] J.James, , p.pandian, A. Switzer, "Egg Shell Ash as Auxiliary Addendum to Lime Stabilization of an Expansive Soil," Journal of Solid Waste Technology and Management, vol.43, no.1, pp.15-25, 2017.

[78] PennDOT, "Engineering Related Properties of Glass Blended with Various Soils," Pennsylvania Department of Transport, Harrisburg, Pennsylvania, USA. 32, 2001b

[79] N. Malasavage, P. Gallaghar, D. Grubb, J. Wartman, M. Carnivale III, "Modifying a plastic clay with crushed glass: implications for constructed fills," Japanese Geotechnical Society, Soils and Foundations 47 (6), pp.1017-1027, 2007.

[80] D. Grubb, A. Davis , M. CarnivaleIII , S. Sands , J. Wartmann, P. Gallagher, "Field evaluation of crushed glass-dredged material blends," Journal of Geotechnical and Geo environmental Engineering 132 (5), pp.577-590, 2006a.

[81] D. Grubb, J. Wartman, P Gallagher, Y. Liu , M. Carnivale III, "Laboratory evaluation of crushed glass-dredged material blends," Journal of Geotechnical and Geo environmental Engineering 132 (5), pp.562576, 2006b.

[82] E. Basari, "Effect of granular waste glass on soil properties," International Conference on New Developments in Soil Mechanics and Geotechnical Engineering, Nicosia, North Cyprus, pp.479-484.

[83] A. Eberemu, J. Edeh, A. Gbolokun, "The geotechnical properties of Lateritic soil treated with crushed glass cullet" Advanced Materials Research 824, pp.21-28, 2013.

[84] A. Fauzi, Z. Djauhari, U. Fauzi, "Soil engineering properties improvement by utilization of cut waste plastic and crushed waste glass as additive," International Journal of Engineering and Technology 8 (1), pp.15-18, 2016.

[85] M. Disfani, A. Arulrajah, M. Ali, M. Bo, "Fine recycled glass: a sustainable alternative to natural aggregates" International Journal of Geotechnical Engineering 5, pp.255-266, 2011a.

[86] M. Disfani, A. Arulrajah, M. Bo, R. Hanhour, "Recycled crushed glass in road work applications," Waste Management 31, pp.2341-2351, 2011 b.

[87] M. Disfani, A. Arulrajah, M. Bo, N. Sivakugan, "Environmental risks of using recycled crushed glass in road applications," Journal of Cleaner Production 20, pp.170-179, 2012. .

[88] PennDOT, "Crushed Glass Fact Sheet," Pennsylvania Department of Transport, Harrisburg, Pennsylvania, USA. 2, 2006.

[89] Dames and Moore, "Glass Feedstock Evaluation Project - Engineering Suitability Evaluation," Clean Washington Center, Seattle, WA, USA, BP-GL-93-95, 110

[90] M. Mavroulidou, M. Ahmed, "Geotechnical properties of glass cullet," Proceedings of the 12th International Conference on Environmental Science and Technology, Rhodes, Greece, pp.678-685, 2011.

[91] N. Consoli, J. Montardo, P. Prietto, G. Pasa, "Engineering Behavior of a Sand Reinforced with Plastic Waste," Journal Of Geotechnical and Geoenvironmental Engineering, vol. 128, pp.462-472, 2002.

[92] S. Peddaiah, A. Burman, S. Sreedeep, "Experimental Study on Effect of Waste Plastic Bottle Strips in Soil Improvement," Geotechnical and Geological Engineering, vol. 36, pp. 2907-2920, 2018. https://doi.org/10.1007/s10706-018-0512-0.

[93] R. Pantawane, A. Agrawal,G. Hatwar, V. Khobragade, V. Chopade, P. Sahare, "Effects of Waste Plastic on Cement Stabilized Soil," International Journal for Research in Applied Science \& Engineering Technology (IJRASET),vol. 7 , Issue III, pp.2162-2168, 2019.

[94] F. Changizi, H. Haddad, "Nano-Particle Coated Natural Fiber Impregnated Soil as a Sustainable Reinforcement Material," Urbanization Challenges in Emerging Economies, pp.435-444, 2015.

[95] C. Kennedy, G. Kabari,L. Prince, "Problematic Clay Soils Modification Using Bush mango Fibre as Stabilizer," International Journal of Civil and Structural Engineering Research, vol.6, Issue 2, pp.43-48, 2019.

[96] S. Bordoloi, D. Patwa, R. Hussain, A. Garg, S. Sreedeep, "Nano-Particle Coated Natural Fiber Impregnated Soil as a Sustainable Reinforcement Material," Urbanization Challenges in Emerging Economies, ASCE India Conference, pp.435-444, 2018. [97] A. Poulose, A. Vasudevan, "Shear Strength Characteristics of Jarofix Treated Cochin Marine Clay," International Journal of Engineering Science and Computing IJESC, vol.8, no.6, pp.18501-18504, 2018.

[98] I. Zorluer, I. Muratoglu, "Effect of Marble Dust on Consolidation Characteristics of Clay Soils," https://www.researchgate.net/publication/268013910 pp.514-517, 2015.

[99] A. Saygili, "Use of Waste Marble Dust for Stabilization of Clayey Soil,” Materials Science (MEDŽIAGOTYRA), vol.21, no. 4, pp.601-606, 2015. [100] F. Yilmaz, M. Yurdakul "Evaluation of Marble Dust for Soil Stabilization,"Special issue of the 3rd International Conference on Computational and Experimental Science and Engineering, vol.132, pp.710711, 2017.

[101] T. Priyanka, S. Rao, "Stabilization of Black Cotton Soil with Marble Dust," International Journal for 
Research in Applied Science \& Engineering Technology (IJRASET), vol.6, no. 5, pp. 2057-2060, 2018.

[102] C. Neeladharan, P. Sathish, A. Nandhini, R. Priya, I.Fathima, J. Srimathi, "Stabilization of Soil by using Marble dust with Sodium silicate as binder," International Journal of Advanced Research Trends in Engineering and Technology (IJARTET), vol.5, pp.4549, 2018.

[103] S. Akbulut, A. Saglamer, "Modification of hydraulic conductivity in granular soils using waste materials," Elsevier, Waste Management, vol.24, pp.491499, 2004.

[104] E. Kalkan, S. Akbulut, "The Positive Effects of Silica Fume on the Permeability, Swelling Pressure and Compressive Strength of Natural Clay Liners," Engineering Geology vol.73, pp.145-156, 2004.

[105] E. Kalkan, "Influence of Silica Fume on the Desiccation Cracks of Compacted Clayey Soils,"Applied Clay Science.vol.43, pp.296-302, 2009.

[106] Z. Khaled, A. Abed, T. Nsayif, "Significance of using a Superpave Gyratory Compactor to Simulate Field Compaction of Fine Grained Soil," Al-Nahrain Journal for Engineering Sciences (NJES), Vol.20 No.3, pp.641646, 2017.

[107] A. Saygili, M. Dayan, "Freeze-thaw behavior of lime stabilized clay reinforced with silica fume and synthetic fibers," Cold Regions Science and Technology, vol. 161, pp.107-114, 2019. 